Hitzert, M., Boesveld, I.C., Hermus, M.A.A., Graaf, J.P. de, Wiegers, T.A., Steegers, E.A.P., Akkermans, H.A. Quality improvement opportunities for handover practices in birth centres: a case study from a process perspective. Journal of Evaluation in Clinical Practice: 2018, 24(3), 590-597

\begin{tabular}{|l|l|}
$\begin{array}{l}\text { Postprint } \\
\text { Version }\end{array}$ & 1.0 \\
\hline Journal website & https://onlinelibrary.wiley.com/doi/abs/10.1111/jep.12939 \\
\hline Pubmed link & $\underline{\text { https://www.ncbi.nlm.nih.gov/pubmed/29878610 }}$ \\
\hline DOI & $10.1111 /$ jep.12939
\end{tabular}

This is a NIVEL certified Post Print, more info at http://www.nivel.eu

\title{
Quality improvement opportunities for handover practices in birth centres: A case study from a process perspective
}

MARIT HitZert PhD, RESEARCHER ${ }^{1}$ | INGE C. BOESVELd PhD, RESEARCHER ${ }^{2}$ | MARIEKE A. A. HeRmus MSC, COMMUNiTy MidWIFE, PHD STUdent ${ }^{3}$ | JOHANNA P. DE GRAAF PHD, SENIOR RESEARCHER ${ }^{1}$ | THERESE A. WIEGERS PHD, SENIOR RESEARCHER IN MIDWIFERY ${ }^{4}$ |

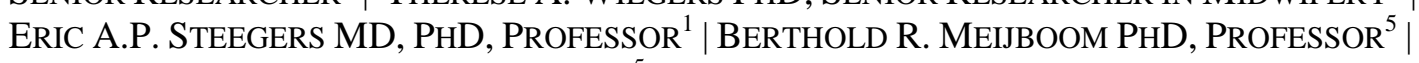
HENK A. AKKERMANS PHD, PROFESSOR ${ }^{5}$

${ }^{1}$ Department of Obstetrics and Gynaecology, Erasmus University Medical Centre, Rotterdam, The Netherlands

2 Jan van Es Institute, Almere, The Netherlands

${ }^{3}$ Department of Child Health, TNO, Leiden, The Netherlands

${ }^{4}$ Nivel, Utrecht, The Netherlands

${ }^{5}$ Tilburg School of Economics and Management, Tilburg, The Netherlands

\begin{abstract}
Rationale, aims and objectives: Handovers within and between health care settings are known to affect quality of care. Health care organizations, struggle how to guarantee best care during handovers. The aim of this paper is to evaluate handover practices in Dutch birth centres from a process perspective, to identify obstacles and opportunities for quality improvements.

Methods: This case study in 7 Dutch birth centres was undertaken from a process perspective by conducting observations and using process mapping. This study is part of the Dutch Birth Centre Study.

Results: Solutions to obstacles during handovers from a birth centre to a hospital were identified in at least 1 of the 7 birth centres. Four of the centres had agreements with a hospital for client support when a caregiver in a birth centre was absent. Face-to-face communication during handover was observed in 6 of the 7 centres. An electronic health record was noted in 1 centre; joint training of acute situations was available in 2 centres with 3 centres indicating that this was not compulsory. Continuity of caregiver was present in 4 birth centres with postpartum care available in 3 centres.

Conclusions: Ensuring quality during handovers requires a case-specific process approach. This study reveals distinctive aspects during handovers, concrete obstacles, and potential solutions for quality improvements in interorganizational networks, transferrable to birth centres in other countries as well.
\end{abstract}


Hitzert, M., Boesveld, I.C., Hermus, M.A.A., Graaf, J.P. de, Wiegers, T.A., Steegers, E.A.P., Akkermans, H.A. Quality improvement opportunities for handover practices in birth centres: a case study from a process perspective. Journal of Evaluation in Clinical Practice: 2018, 24(3), 590-597

\section{INTRODUCTION}

Handovers are a serious issue in health care as they are known to affect quality of care.1-3 Often, the organization of health care services requires the client to move between services, such as from primary care to secondary care, across team shifts, and disciplines. These handovers serve as the basis for transferring responsibility (being in charge) and accountability (liability) for the care of clients. 4

One area of health care where there has long been a debate on the effectiveness and the safety of the operational set-up of the care processes is the maternity care system. The debate around the Dutch system increased after the results became known from the 2008 edition of the EURO-PERISTAT study, which put the Netherlands in perinatal health outcomes close to the bottom of a ranked list of European countries.5 The historical organization of the Dutch maternity system has a clear segmentation in primary care (community midwife-led) and secondary care (obstetrician-led). In the Netherlands, pregnant women with an uncomplicated pregnancy can choose where they would like the birth to take place: at home, in a hospital, or in a birth centre. The number of birth centres in the Netherlands has increased rapidly over the last 15 years. Many birth centres have been established in other countries as well, including the United States, the United Kingdom, Australia, and Sweden.6-9 Birth centres are midwifery-managed locations that offer care during labour and birth to women with uncomplicated pregnancies. They have a homelike environment and provide facilities to support physiological birth. Community midwives take primary professional responsibility for care, assisted by maternity care assistants. 10 Most Dutch community midwives work in group practices in the community. They are autonomous in their decisions during birth care. When a complication occurs or medical assistance for pharmacological pain relief is requested, the woman will be referred to a secondary care obstetric hospital unit. Depending on the reason for referral, either the obstetrician or the paediatrician takes over responsibility of care from the community midwife. Reasons for referral are defined in the List of Obstetric Indications, which is a multidisciplinary guideline.11 Birth centres are often located close to the obstetric care unit of a hospital but can be freestanding from a hospital as well.10, 12

The clear segmentation in primary and secondary care requires the pregnant women to move often from 1 type of service to another. During the birth process, health care is essential to guarantee the health and life of the mother and her baby. Transfers during labour or birth can undermine this, because time is a factor that directly affects maternal and child health.13-15 In the Netherlands, research has shown that a total of $70.1 \%$ of nulliparous women (women who have not given birth before) who wanted to give birth in a birth centre were referred to the hospital during or after childbirth. A total of $31.8 \%$ of multiparous women (women who have given birth before) who wanted to give birth in a birth centre were referred to the hospital during or after childbirth. These were mostly non-urgent referrals including pain relief.16 Inappropriate risk assessment, regional variations in process and outcome aspects, and poor communication between community midwives and obstetricians are often topic of discussion on handover processes in and outside the Netherlands.17-21 Standards or best practices for handovers in (Dutch) birth centres are not available. The aim of this paper is to evaluate handover practices in Dutch birth centres from a 
Hitzert, M., Boesveld, I.C., Hermus, M.A.A., Graaf, J.P. de, Wiegers, T.A., Steegers, E.A.P., Akkermans, H.A. Quality improvement opportunities for handover practices in birth centres: a case study from a process perspective. Journal of Evaluation in Clinical Practice: 2018, 24(3), 590-597

process perspective, to identify obstacles and opportunities for evidence based quality improvements.

\section{METHODS}

\subsection{Design}

Case study research has been applied since it allows answering questions regarding the "how," "what," and "why" aspects with a full understanding of the nature and complexity of the phenomenon.22-25 Case study research is particularly appropriate for early, exploratory investigations, 23 like this study is.

This multiple case study was undertaken from a process perspective by conducting observations and using process mapping with a Business Process Model and Notation (BPMN) approach. BPMN illustrates the workflow (interrelated work activities and resources) in organizations readily understandable by all stakeholders. The whole work process crosses several functions or other organization entities, which is illustrated on the map.26 The handover practices were evaluated in 7 Dutch birth centres, and possible obstacles and opportunities for quality improvements were identified.

This study is part of the Dutch Birth Centre Study.27 The national project evaluates the effect of Dutch birth centre care on aspects such as effectiveness, costeffectiveness, and experiences. To better understand the whole phenomenon "birth centres," we did not look only into health outcomes, client experiences, and costs but also into the processes that lead to and, thereby, influence these outcomes.

\subsection{Sample}

After an initial first exploratory round of visits to 15 birth centres in the Netherlands, 7 birth centres were selected with the aim to achieve a maximum variation, see Table 1. The main criteria for case selection included variation in geographical location, spread in operational period, and variation in type of birth centre based on location with respect to the obstetric unit. Three types of birth centres can be distinguished: (1) freestanding birth centres, (2) birth centres alongside the obstetric unit, and (3) birth centres on-site the obstetric unit.10

\section{[TABLE 1]}

\subsection{Data collection}

The data collection is based on a triangulation of different types of data: comprehensive field notes of direct observations of the professional staff working in the 7 birth centres, informal conversations with them, and studying of documents, including policy documents and agreements. These documents were obtained from the managers of the birth centres. Furthermore, a researcher (M. H.) measured twice the distance (in time) between the birth centre and the nearest hospital obstetric care unit by enacting a transfer and an average time has been calculated. The researcher (M. H.) made field notes of the observations of the daily operations and informal conversations in the birth centres. To focus on the observations, sensitizing concepts are used. 28

To direct the study, these sensitizing concepts are discussed and specified during the data collection period by the researchers (M. H. and H.A.A.). Equally spread over the 7 birth centres, the observations took in total around 1000 hours (based on 
Hitzert, M., Boesveld, I.C., Hermus, M.A.A., Graaf, J.P. de, Wiegers, T.A., Steegers, E.A.P., Akkermans, H.A. Quality improvement opportunities for handover practices in birth centres: a case study from a process perspective. Journal of Evaluation in Clinical Practice: 2018, 24(3), 590-597

saturation), during day, night, weekdays, and weekend, spread over 1 year (April 2013 to April 2014). A high number of observation hours were needed to account for periods of low activity in the birth centre.

\subsection{Ethical considerations}

Oral informed consent was obtained from the management team and clients of the birth centres. The design and planning of the study were presented to the Medical Ethics Committee of the University Medical Centre Utrecht. They confirmed that an official ethical approval of this study is not required.29

\subsection{Data analysis}

Analysis started as soon as the first data were collected and continued with each additional observation. Atlas software was used for data management of the observations, informal conversations, and (policy) documents and analysis. The first step in the analysis was coding the transcripts of the observations and informal conversations. Codes that relate closely to the text fragments (eg presence of caregivers, transport, continuity of care, and information exchange) were used. After a while, 2 researchers (M. H. and H. A. A.) discussed them. The coded transcripts were then analysed to identify returning topics of which handover practices is one. In a common meeting the observed handover processes were discussed with employees of each birth centre (including community midwives, maternity care assistants, obstetricians, and managers; on average 5 caregivers per birth centre). The result of the meeting was a sketched process map. This sketched process map supported the employees by identifying possible obstacles and opportunities for quality improvement. All their comments were documented in notes and analysed. After the meeting, a Business Process Management tool (BPMN 2.0 Signavio) was used by the researcher to map the current processes. This was a common understanding of the process capturing the physical journey, the flows of information, and responsibilities.

Analysing from a process perspective acknowledges the importance of the context to an understanding of why interventions and strategies work, how, and under which circumstances.30 Two of the researchers (M. H. and H.A.A.) compared the 7 maps and identified the differences in obstacles and opportunities. As a member check to validate the qualitatively generated data, the process maps were given back to the managers of the birth centres. All the managers confirmed that the interpretation of the processes was accurate.

\section{RESULTS}

\subsection{Handover practices}

We observed that there were distinctive aspects about the handover practices in every birth centre. As an example of the process mapping, Figure 1 provides an overview of the observed care processes in 1 birth centre (D), including the handovers, from the start of labour to postpartum care at home. 
Hitzert, M., Boesveld, I.C., Hermus, M.A.A., Graaf, J.P. de, Wiegers, T.A., Steegers, E.A.P., Akkermans, H.A. Quality improvement opportunities for handover practices in birth centres: a case study from a process perspective. Journal of Evaluation in Clinical Practice: 2018, 24(3), 590-597

\section{[FIGURE 1]}

The figure consists of 3 lanes that represent the organization parts: the upper lane is the client's home, the middle lane represents the birth centre, and the lower lane is the hospital. The process starts upper left at the client's home.

Different kinds of caregivers are involved during the handovers from a birth centre to a hospital. In the birth centre, the maternity care assistant/birth assistant assists the community midwife during childbirth and works under the supervision of the community midwife. 31 The independently operating community midwife is responsible and assists women with uncomplicated pregnancies during childbirth and the postpartum period in a birth centre. If complications occur or medical assistance for pharmacologic pain relief is requested, she refers them to an obstetrician or paediatrician.31 Pharmacologic pain relief is given by an anaesthetist. Not all midwives in the Netherlands are independent practitioners; some are employed in the hospital setting. These clinical midwives function semi-autonomously within the hospital setting under the responsibility of and together with obstetricians. 32 The obstetrician accompanies childbirths that require more complex and specialized care, and the tasks of the paediatrician include caring for premature babies, babies with a low birthweight, or signs of infection. In the event the care takes place in the hospital, an obstetric nurse of the obstetric unit assists the clinical midwife or obstetrician during childbirth.

Distinctive aspects are summarized in Table 2 for all 7 birth centres. In a few birth centres, no matter if clients are present or not, the caregivers are standard present in the birth centre. In other birth centres they are not, the caregivers arrive in the birth centre when a woman in labour calls. If the client is already in the birth centre and professional help is needed while the community midwife and/or maternity care assistants is/are not there yet, the clinical midwife and/or nurse, working in the hospital, temporarily take(s) over the responsibility of care. This is not the case in all birth centres; in 1 birth centre, there is no caregiver working in the hospital to momentarily take over the responsibility of care in the birth centre and the client who is in labour has to wait in the corridor without professional help.

In case of referral from the birth centre to the hospital, the caregivers of the hospital are informed through face-to-face or telephone communication. The medical history is transferred on paper or digitally. The transfer of the client from a birth centre to hospital is done in 1 birth centre by ambulance/car, in some birth centres, by wheelchair or bed. In some birth centres, no transport is needed; the caregivers change room. Exceptions for transfer are locally described and included situations as shoulder dystocia, resuscitation of the neonate, and postpartum haemorrhage. In those situations, the protocol is that the secondary caregiver (clinical nurse/obstetrician or paediatrician) is called and has to come from the hospital to the birth centre for referral. Average transfer times between the birth centres and the hospitals vary between less than 1 minute and 20 minutes.

In some birth centres, when all birthing rooms at the hospital are occupied during a referral, the birth takes place in the birth centre. The woman does not get transferred, and the obstetrician comes to the birth centre to take over the responsibility of care during birth. In other birth centres, the client and community midwife have to go by 
Hitzert, M., Boesveld, I.C., Hermus, M.A.A., Graaf, J.P. de, Wiegers, T.A., Steegers, E.A.P., Akkermans, H.A. Quality improvement opportunities for handover practices in birth centres: a case study from a process perspective. Journal of Evaluation in Clinical Practice: 2018, 24(3), 590-597

car/ambulance to another hospital. The continuity of care postpartum differs across the 7 birth centres. In some birth centres, the client goes home (with her medical record on paper) a few hours after birth. The maternity care assistant who will provide care at home gets informed by phone or fax. In 1 birth centre, the same maternity care assistants as those during birth join the client at home. In a few birth centres, it is possible to stay in that birth centre a few days after birth.

\section{[TABLE 2]}

\subsection{Quality obstacles}

Seven quality obstacles (caregiver absence on arrival, no direct contact during handover, use of multiple electronic health records, inadequate caregiver's knowledge on procedures, unfamiliarity with team members, no continuity of caregiver, and no continuity of care for client) were identified and are summarized in Table 3 for all 7 birth centres. The 7 obstacles can interrupt the continuity of intrapartum and postpartum care (in acute situations), lead to missing information during key moments and influence the collaboration.

\section{[TABLE 3]}

\subsection{QUALITY IMPROVEMENTS}

Potential solutions to the aforementioned quality obstacles were identified. All these solutions were observed in at least 1 of the 7 settings studied. In summary, 4 of the 7 birth centres had agreements with the hospital for client support when a caregiver was absent. Face to face communication during handover was observed in 6 of the 7 birth centres. An electronic health record was noted in 1 birth centre; joint training of acute situations with maternity care assistants, (community) midwives, nurses, obstetricians, and paediatricians was available in 2 birth centres (compulsory) with 3 centres indicating that this was not compulsory. Continuity of caregiver was present in 4 birth centres with postpartum care available in 3 centres.

\section{DISCUSSION}

In this study, our aims were (1) to evaluate handover practices in birth centres from a process perspective, (2) to identify possible obstacles, and (3) opportunities for quality improvements in the practice of handovers in birth centres.

\subsection{Strengths and limitations}

To our knowledge, this is the first study that is undertaken from a process perspective to identify obstacles and facilitators of handover practices in inter-organizational networks by using observations and process mapping. Process mapping can be effective in evaluating whether or not improvements to the current operational process, including handovers, are possible and desirable.1

We used a BPMN approach to map to processess. BPMN is designed for different kinds of users, which makes it suitable for maternity care process modelling. With this approach, it is possible to model different events and exceptions for routing a process. This matches with the health care processes and more specific the maternity care processes, which tend to have many exceptions.33 Until now application of process mapping in maternity care is somewhat limited.34 This perspective allowed 
Hitzert, M., Boesveld, I.C., Hermus, M.A.A., Graaf, J.P. de, Wiegers, T.A., Steegers, E.A.P., Akkermans, H.A. Quality improvement opportunities for handover practices in birth centres: a case study from a process perspective. Journal of Evaluation in Clinical Practice: 2018, 24(3), 590-597

us to explicitly analyse relationships and interactions between caregivers that are involved in the care process 30 and should therefore be used more often in health care.

Although the validity of the data was increased by our observations of the care process in the natural setting, 35 all these observations were assessed by a single researcher. As a member check to validate the qualitatively generated data, the process maps were given back to the managers of the birth centres. All the managers confirmed that the interpretation of the processes was accurate.

Birth centres have internationally been studied from the point of various domains, all focussing on structure and performance outcomes instead of the process.36-39 Beside this, the studies are mainly based on quantitative data. These studies ignore the "black box" of how processes link structure to outcome. This article contributes to a broad evaluation of birth centre care.27 It is 1 of the sub-studies based on data from the Dutch Birth Centre Study. The aim of this national study was to provide evidence-based recommendations for birth centre care in the Netherlands. To make these recommendations, all sub-studies (most of them focussing on performance outcomes) of the Dutch Birth Centre Study must be considered. These recommendations are (partly) transferable to birth centres in other countries, including the United States, the United Kingdom, Australia, and Sweden.

\section{DISCUSSION}

This study can be used to increase awareness on handover processes in birth centres in and outside the Netherlands. It demonstrated differences in handover processes between birth centres. Every (unnecessary) process interrupts the process of physiologic childbirth.40 Evaluation and adjustment of these processes can lead to more optimal outcomes. Awareness of differences between birth centres can be the first step to change practice.

Solutions to obstacles during handovers from a birth centre to a hospital were identified in at least 1 of the 7 birth centres. Four of the centres had agreements with a hospital for client support when a caregiver in a birth centre was absent. These agreements ensure that there will always be someone to take care of the client when she arrives in the birth centre. In a freestanding birth centre, which is separated from a hospital with obstetric services, the community midwife should make sure she arrives together with the client.

Face-to-face communication during handover was observed in 6 of the 7 centres. An electronic health record was noted in only one of the 7 birth centres. The other 6 birth centres use a paper hand-held record for sharing information. The use of an electronic health record has demonstrated significant improvements to the collection of best practice variables in a maternity care setting. 41 Additionally, the data in an electronic health record were more available to relevant caregivers and more easily retrieved than from a paper hand-held record. The aforementioned aspects improve efficiency and reduce errors.

Joint training of acute situations was available in 2 centres with 3 centres indicating that this was not compulsory. In some situations, critical communication must occur, often at potentially highly stressful times. To prevent (communication) errors, it is important to focus the training on the team as a whole. Obstetrics is a field in which several professionals have to work together under extreme time pressure.42, 43 During the training, the caregivers (obstetricians and paediatricians) who come only 
Hitzert, M., Boesveld, I.C., Hermus, M.A.A., Graaf, J.P. de, Wiegers, T.A., Steegers, E.A.P., Akkermans, H.A. Quality improvement opportunities for handover practices in birth centres: a case study from a process perspective. Journal of Evaluation in Clinical Practice: 2018, 24(3), 590-597

to the birth centre in acute situations will become more familiar with the birth centre setting and their colleagues.

Continuity of caregiver was present in 4 birth centres with postpartum care available in 3 centres. (Un)Familiarity of the woman with the caregiver is an aspect that can largely explain the differences in client experiences between transferred and nontransferred women.44, 45 These experiences are an important indicator of the quality of health care. In the Netherlands, pregnant women are often familiar with their community midwife. In case of referral to secondary care, a pregnant woman meets new caregivers with whom she is not familiar. Because of the segmentation of primary and secondary care, it is difficult to guarantee a familiar caregiver. One possible solution would be a community midwife, who continues accompanying the woman.

Above suggested solutions are all based on the results of this multiple case study. The other sub-studies of the Dutch Birth Centre Study give solutions according to handover obstacles as well. One of the sub-studies has shown a high number of referrals for women who planned birth in a birth centre.16 Referrals have a direct effect on the outcomes, as referral often leads to the start of cascade of interventions. Need for pain relief is one of the most important reasons for referral. After the data collection of the Dutch Birth Centre Study, nitrous oxide was introduced in birth centres to be used as an alternative analgesia for use during labour. This introduction may result in a lower number of referrals to a hospital. Another sub-study of the Dutch Birth Centre Study showed that a referral to the hospital had a negative effect on the experiences of women, while the physical transfer from the birth centre to the obstetric unit was not experienced as a problem.36 Above findings make clear that to make recommendations to improve birth centre care in and outside the Netherlands, all sub-studies of the Dutch Birth Centre Study must be considered.

\section{CONCLUSIONS}

Ensuring quality during handovers requires a case-specific process approach to understand and improve care. Through analysis from a process perspective, this study reveals distinctive aspects during handovers, identifies 7 concrete obstacles and 6 potential solutions, which might be transferrable to birth centres outside the Netherlands.

\section{IMPLICATIONS}

In the last decades, many birth centres have been established in different countries. Birth centres are settings that uphold the maternity care system in which (community) midwives take responsibility for births of women with low risk of complications, in a non-clinical setting. This functional set-up often requires the client to move from one type of service to another. These handovers increase the opportunity for errors and have a negative effect on client experiences. They cannot always be prevented and must, therefore, be organized as optimal as possible. This study provides potential solutions for that.

\section{Acknowledgements}

This work was supported by the Netherlands Organization for Health Research and Development (ZonMw) (grant no. 209020012). This funding source had no role in 
Hitzert, M., Boesveld, I.C., Hermus, M.A.A., Graaf, J.P. de, Wiegers, T.A., Steegers, E.A.P., Akkermans, H.A. Quality improvement opportunities for handover practices in birth centres: a case study from a process perspective. Journal of Evaluation in Clinical Practice: 2018, 24(3), 590-597

the design of the study, execution, analyses, interpretation of the data, or decision to submit results.

\section{Conflicts of interest}

The authors declare no conflict of interest.

\section{REFERENCES}

1Johnson JK, Farnan JM, Barach P, et al. Searching for the missing pieces between the hospital and primary care: mapping the patient process during care transitions. BMJ Qual Saf,bmjqs-2012-001215. 2012;21(Suppl 1):i97-i105.

2Wachter R. Understanding Patient Safety. 2. New York, NY: McGraw-Hill Medical; 2012. 3Dixon JL, Stagg HW, Wehbe-Janek H, Jo C, Culp Jr WC, Shake JG. A standard handoff improves cardiac surgical patient transfer: operating room to intensive care unit. J Healthc Qual. 2015;37(1):22-32.

4Marlow C. Communication is key. ANMJ. 2017;24(8):26.

5 Mohangoo A, Buitendijk S, Hukkelhoven $C$, et al. Higher perinatal mortality in the Netherlands than in other European countries: the Peristat-II study. Ned Tijdschr Geneeskd. 2008;152(50):2718-2727.

6Bennetts A, Lubic RW. The free-standing birth centre. The Lancet. 1982;319(8268):378380.

7Schroeder E, Petrou S, Patel N, et al. Cost effectiveness of alternative planned places of birth in woman at low risk of complications: evidence from the Birthplace in England national prospective cohort study. BMJ. 2012;344(apr18 3):e2292.

8Waldenström U, Lawson J. Birth centre practices in Australia. ANZJOG. 1998;38(1):42-50.

9Waldenstrom U, Nilsson CA, Winbladh B. The Stockholm birth centre trial: maternal and infant outcome. BJOG. 1997;104(4):410-418.

10 Hermus MA, Boesveld I, Hitzert M, et al. Defining and describing birth centres in the Netherlands-a component study of the Dutch Birth Centre Study. BMC Pregnancy Childbirth. 2017;17(1):210.

11Zorgverzekeringen, C. V. (2003) Verloskundig vademecum. Eindrapport van de Commissie Verloskunde van het College voor Zorgverzekeringen. [Obstetrical manual Final report of the Obstetric working Group of the National Health Insurance Board CVZ]. In, Diemen.

12Wiegers T, de Graaf H, van der Pal K. De opkomst van geboortecentra en hun rol in de zorg. Tijdschrift voor Gezondheidswetenschappen. 2012;90(8):475-478.

13De Graaf J, Ravelli A, Visser G, et al. Increased adverse perinatal outcome of hospital delivery at night. BJOG. 2010;117(9):1098-1107.

14Ravelli A, Jager K, De Groot M, et al. Travel time from home to hospital and adverse perinatal outcomes in women at term in the Netherlands. BJOG. 2011;118(4):457-465.

15Grzybowski S, Stoll K, Kornelsen J. Distance matters: a population based study examining access to maternity services for rural women. BMC Health Serv Res. 2011;11(1):147.

16Hermus MA, Hitzert M, Boesveld IC, et al. Differences in optimality index between planned place of birth in a birth centre and alternative planned places of birth, a nationwide prospective cohort study in the Netherlands: results of the Dutch Birth Centre Study. BMJ Open. 2017;7(11):e016958.

17Evers ACC, Brouwers HAA, Hukkelhoven CWPM, et al. Perinatal mortality and severe morbidity in low and high risk term pregnancies in the Netherlands: prospective cohort study. BMJ. 2010;341(nov02 2):c5639.

18Bonsel GJ, Birnie E, Denktas S, Poeran J, Steegers EAP. Dutch report: Lijnen in de perinatale sterfte, Signalementstudie Zwangerschap en Geboorte 2010. Rotterdam: Erasmus MC; 2010.

19Visser GHA. Obstetric care in the Netherlands: relic or example. J Obstet Gynaecol Can. 2012;34(10):971-975. 
Hitzert, M., Boesveld, I.C., Hermus, M.A.A., Graaf, J.P. de, Wiegers, T.A., Steegers, E.A.P., Akkermans, H.A. Quality improvement opportunities for handover practices in birth centres: a case study from a process perspective. Journal of Evaluation in Clinical Practice: 2018, 24(3), 590-597

20Crofts JF, Fox R, Ellis D, Winter C, Hinshaw K, Draycott TJ. Observations from 450 shoulder dystocia simulations: lessons for skills training. Obstet Gynecol. 2008;112(4):906912.

21Raine R, Cartwright M, Richens Y, Mahamed Z, Smith D. A qualitative study of women's experiences of communication in antenatal care: identifying areas for action. Matern Child Health J. 2010;14(4):590-599.

22Eisenhardt KM. Building theories from case study research. Acad Manage Rev. 1989;14(4):532-550.

23Yin RK. Case Study Research: Design and Methods. Sage publications; 2014.

24Siggelkow N. Persuasion with case studies. Acad Manage J. 2007;50(1):20-24.

25 Meredith J. Building operations management theory through case and field research. $J$ Oper Manage. 1998;16(4):441-454.

26Anjard R. Process mapping: a valuable tool for construction management and other professionals. Facilities. 1998;16(3/4):79-81.

27Hermus M, Wiegers T, Hitzert M, et al. The Dutch Birth Centre Study: study design of a programmatic evaluation of the effect of birth centre care in the Netherlands. BMC Pregnancy Childbirth. 2015;15(1):148.

28Blumer $\mathrm{H}$. The methodological position of symbolic interactionism. Symbolic Interactionism: Perspective and Method. 1969;1-60.

29 Central Committee on Research Involving Human Subjects. In.

30 Hines $\mathrm{P}$, Rich N. The seven value stream mapping tools. Int J Oper Prod Manag. 1997;17(1):46-64.

31 Van Teijlingen ER. The profession of maternity home care assistant and its significance for the Dutch midwifery profession. Int J Nurs Stud. 1990;27(4):355-366.

32 Wiegers TA, Hukkelhoven CW. The role of hospital midwives in the Netherlands. BMC Pregnancy Childbirth. 2010;10(1):80.

33Aguilar-Saven RS. Business process modelling: review and framework. Int J Prod Econ. 2004;90(2):129-149.

34Jun GT, Ward J, Morris Z, Clarkson J. Health care process modelling: which method when? Int J Qual Health Care. 2009;21(3):214-224. mzp016

35 Holloway I, Galvin K. Qualitative research in nursing and healthcare. John Wiley \& Sons; 2016.

36Hitzert M, Hermus MA, Scheerhagen M, et al. Experiences of women who planned birth in a birth centre compared to alternative planned places of birth. Results of the Dutch Birth Centre Study. Midwifery. 2016;40:70-78.

37Dahlen HG, Dowling H, Tracy M, Schmied V, Tracy S. Maternal and perinatal outcomes amongst low risk women giving birth in water compared to six birth positions on land. A descriptive cross sectional study in a birth centre over 12 years. Midwifery. 2013;29(7):759764.

38Li Y, Townend J, Rowe R, Knight M, Brocklehurst P, Hollowell J. The effect of maternal age and planned place of birth on intrapartum outcomes in healthy women with straightforward pregnancies: secondary analysis of the Birthplace national prospective cohort study. BMJ Open. 2014;4(1):e004026.

39Kuliukas L, Hauck Y, Duggan R, Lewis L. The phenomenon of intrapartum transfer from a western Australian birth centre to a tertiary maternity hospital: the overall experiences of partners. Midwifery. 2015;31(5):e87-e93.

40Tew M. Safer childbirth?: a critical history of maternity care. Springer; 2013.

41Hawley G, Jackson C, Hepworth J, Wilkinson SA. Sharing of clinical data in a maternity setting: how do paper hand-held records and electronic health records compare for completeness? BMC Health Serv Res. 2014;14(1):650.

42Merién A, Van de Ven J, Mol B, Houterman S, Oei S. Multidisciplinary team training in a simulation setting for acute obstetric emergencies: a systematic review. Obstet Gynecol. 2010;115(5):1021-1031.

43van de Ven J, Houterman S, Steinweg RA, et al. Reducing errors in health care: costeffectiveness of multidisciplinary team training in obstetric emergencies (TOSTI study); a randomised controlled trial. BMC Pregnancy Childbirth. 2010;10(1):59. 
Hitzert, M., Boesveld, I.C., Hermus, M.A.A., Graaf, J.P. de, Wiegers, T.A., Steegers, E.A.P., Akkermans, H.A. Quality improvement opportunities for handover practices in birth centres: a case study from a process perspective. Journal of Evaluation in Clinical Practice: 2018, 24(3), 590-597

44Scheerhagen M, Van Stel HF, Birnie E, Franx A, Bonsel GJ. Measuring client experiences in maternity care under change: development of a questionnaire based on the WHO responsiveness model. PLoS One. 2015;10(2):e0117031.

45van Stenus CM, Boere-Boonekamp MM, Kerkhof EF, Need A. Client satisfaction and transfers across care levels of women with uncomplicated pregnancies at the onset of labor. Midwifery. 2017;48:11-17.

\section{TABLES}

Table 1. Characteristics of the cases

\begin{tabular}{|c|c|c|c|c|c|c|}
\hline $\begin{array}{l}\text { Birth } \\
\text { centre }\end{array}$ & initiators & $\begin{array}{c}\text { Reason of } \\
\text { establishment }\end{array}$ & Since & type of region & $\begin{array}{l}\text { Location of } \\
\text { birth centre }\end{array}$ & $\begin{array}{c}\text { Number } \\
\text { of births } \\
\text { in } 2013 \\
\end{array}$ \\
\hline A & Insurance company & $\begin{array}{l}\text { Distance to a hospital } \\
\text { for emergency care } \\
\text { during home birth is } \\
\text { otherwise too long } \\
\end{array}$ & 2009 & $\begin{array}{l}\text { Small city in a } \\
\text { rural area }(1300 \\
\text { inhabitants per } \\
\left.\mathrm{km}^{2}\right)\end{array}$ & Freestanding & 113 \\
\hline $\mathrm{B}$ & $\begin{array}{l}\text { Ten community midwifery } \\
\text { practices }\end{array}$ & $\begin{array}{l}\text { The higher demand for } \\
\text { hospital births leaded to } \\
\text { capacity shortfall of the } \\
\text { obstetric care unit. }\end{array}$ & 2007 & $\begin{array}{l}\text { Large city } \\
(4888 \\
\text { inhabitants per } \\
\left.\mathrm{km}^{2}\right)\end{array}$ & Alongside & 1090 \\
\hline $\mathrm{C}$ & Community midwives & $\begin{array}{l}\text { Maintenance and } \\
\text { strengthening maternity } \\
\text { care to support the } \\
\text { physiological birth. }\end{array}$ & 2012 & $\begin{array}{l}\text { Small city } \\
(1183 \\
\text { inhabitants per }^{2} \\
\left.\mathrm{~km}^{2}\right)\end{array}$ & Alongside & 235 \\
\hline $\mathrm{D}$ & $\begin{array}{l}\text { Community midwives, } \\
\text { obstetricians, organization } \\
\text { of maternity care, insurance } \\
\text { company, board of the } \\
\text { hospital and the } \\
\text { municipality }\end{array}$ & $\begin{array}{l}\text { The higher demand for } \\
\text { hospital births leaded to } \\
\text { capacity shortfall of the } \\
\text { obstetric care unit. }\end{array}$ & 2009 & $\begin{array}{l}\text { Large city } \\
(2960 \\
\text { inhabitants per } \\
\left.\mathrm{km}^{2}\right)\end{array}$ & Alongside & 734 \\
\hline $\mathrm{E}$ & Community midwives & $\begin{array}{l}\text { The higher demand for } \\
\text { hospital births leaded to } \\
\text { capacity shortfall of the } \\
\text { obstetric care unit. }\end{array}$ & 2004 & $\begin{array}{l}\text { Large city } \\
(3481 \\
\text { inhabitants per } \\
\left.\mathrm{km}^{2}\right)\end{array}$ & On-site & 888 \\
\hline $\mathrm{F}$ & $\begin{array}{l}\text { Maternity care professionals } \\
\text { from different backgrounds }\end{array}$ & $\begin{array}{l}\text { Intensive collaboration } \\
\text { to enhance quality in } \\
\text { maternity care }\end{array}$ & 2011 & $\begin{array}{l}\text { Medium-size } \\
\text { city }(1794 \\
\text { inhabitants per } \\
\left.\mathrm{km}^{2}\right)\end{array}$ & On-site & 402 \\
\hline G & $\begin{array}{l}\text { Board of the hospital, } \\
\text { community midwives and } \\
\text { obstetricians }\end{array}$ & $\begin{array}{l}\text { Strengthening obstetric } \\
\text { and midwifery care }\end{array}$ & 2013 & $\begin{array}{l}\text { Medium-size } \\
\text { city }(2037 \\
\text { inhabitants per } \\
\left.\mathrm{km}^{2}\right)\end{array}$ & On-site & $\begin{array}{l}264 \text { (since } \\
\text { May) }\end{array}$ \\
\hline
\end{tabular}


Hitzert, M., Boesveld, I.C., Hermus, M.A.A., Graaf, J.P. de, Wiegers, T.A., Steegers, E.A.P.,

Akkermans, H.A. Quality improvement opportunities for handover practices in birth centres: a

case study from a process perspective. Journal of Evaluation in Clinical Practice: 2018, 24(3),

590-597

FIGURE 1 The process map of birth Centre D

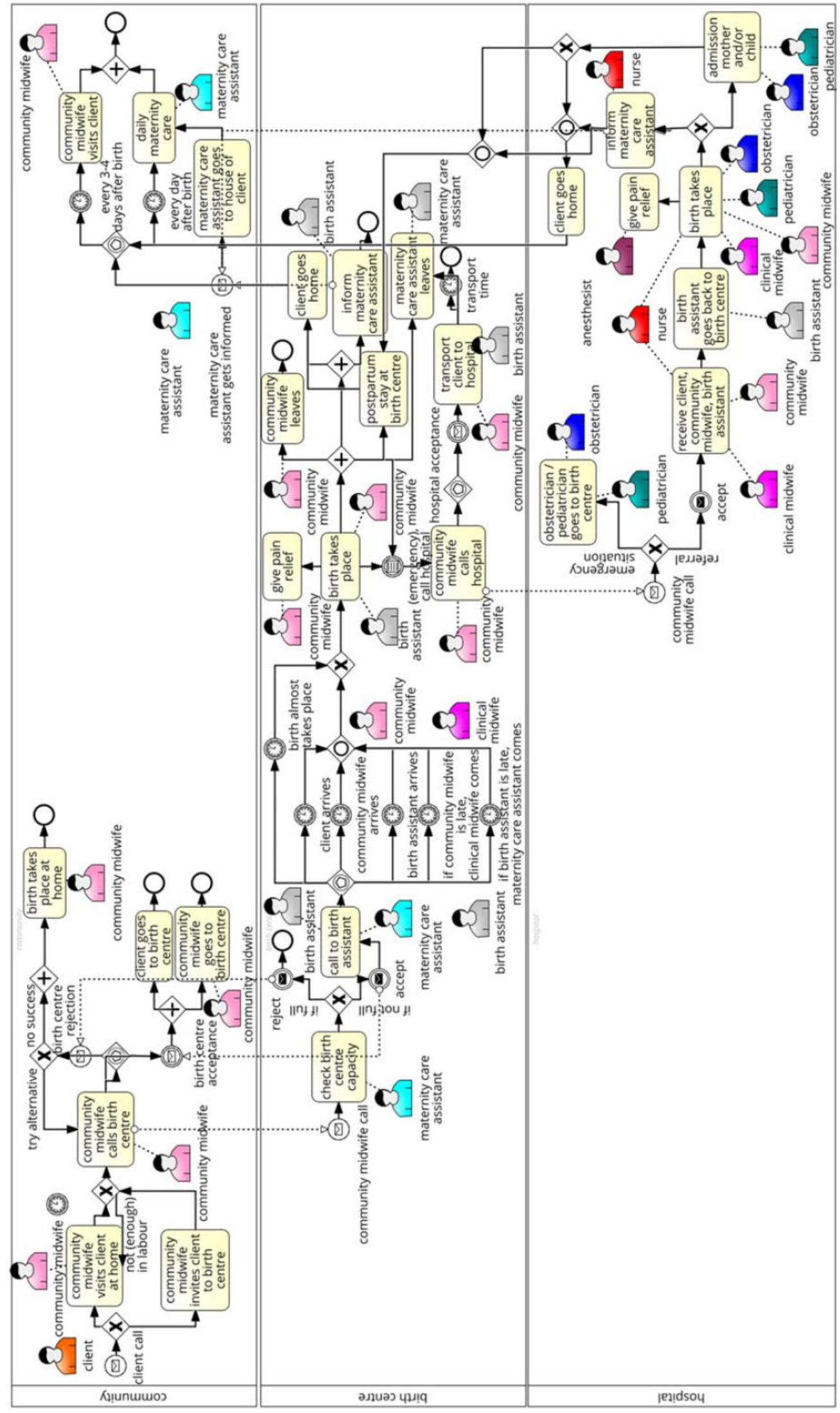


Hitzert, M., Boesveld, I.C., Hermus, M.A.A., Graaf, J.P. de, Wiegers, T.A., Steegers, E.A.P., Akkermans, H.A. Quality improvement opportunities for handover practices in birth centres: a case study from a process perspective. Journal of Evaluation in Clinical Practice: 2018, 24(3), 590-597

Table 2. Results of the 7 birth centres on handover practices from a process perspective

\begin{tabular}{|c|c|c|c|c|c|}
\hline $\begin{array}{l}\text { Birth } \\
\text { centre }\end{array}$ & $\begin{array}{l}\text { Progress of } \\
\text { birth }\end{array}$ & $\begin{array}{c}\text { Standard } \\
\text { presence of } \\
\text { caregivers in } \\
\text { birth centre }\end{array}$ & $\begin{array}{l}\text { Transfer from } \\
\text { birth centre to } \\
\text { the hospital }\end{array}$ & $\begin{array}{c}\text { Transmission of } \\
\text { information during } \\
\text { referral }\end{array}$ & $\begin{array}{l}\text { Possibility to stay } \\
\text { postpartum in } \\
\text { birth centre }\end{array}$ \\
\hline $\mathbf{A}$ & $\begin{array}{l}\text { Checked } \\
\text { during home- } \\
\text { visit }\end{array}$ & No & $\begin{array}{l}\text { By ambulance } \\
\text { or car }\end{array}$ & $\begin{array}{l}\text { On paper, } \\
\text { community midwife } \\
\text { consults caregivers } \\
\text { by phone }\end{array}$ & $\begin{array}{l}\text { No, the client goes } \\
\text { home, if possible } \\
\text { with the same } \\
\text { maternity care } \\
\text { assistant }\end{array}$ \\
\hline B & $\begin{array}{l}\text { Checked } \\
\text { during home- } \\
\text { visit or in the } \\
\text { birth centre }\end{array}$ & $\begin{array}{l}\text { No } \\
\text { Hospital } \\
\text { support } \\
\text { available }\end{array}$ & $\begin{array}{l}\text { By wheelchair } \\
\text { or bed and } \\
\text { exceptions for } \\
\text { transfer are } \\
\text { locally } \\
\text { described }\end{array}$ & $\begin{array}{l}\text { On paper, } \\
\text { community midwife } \\
\text { consults caregivers } \\
\text { by phone }\end{array}$ & $\begin{array}{l}\text { No and no } \\
\text { maternity care } \\
\text { assistance at night } \\
\text { at home }\end{array}$ \\
\hline C & $\begin{array}{l}\text { Checked } \\
\text { during home- } \\
\text { visit }\end{array}$ & No & $\begin{array}{l}\text { By wheelchair } \\
\text { or bed and } \\
\text { exceptions for } \\
\text { transfer are } \\
\text { locally } \\
\text { described }\end{array}$ & $\begin{array}{l}\text { On paper, } \\
\text { community midwife } \\
\text { consults caregivers } \\
\text { by phone }\end{array}$ & $\begin{array}{l}\text { No and no } \\
\text { maternity care } \\
\text { assistance at night }\end{array}$ \\
\hline D & $\begin{array}{l}\text { Checked } \\
\text { during home- } \\
\text { visit or in the } \\
\text { birth centre }\end{array}$ & $\begin{array}{l}\text { Yes } \\
\text { Hospital } \\
\text { support } \\
\text { available }\end{array}$ & $\begin{array}{l}\text { By wheelchair } \\
\text { or bed and } \\
\text { exceptions for } \\
\text { transfer are } \\
\text { locally } \\
\text { described } \\
\end{array}$ & $\begin{array}{l}\text { On paper, } \\
\text { community midwife } \\
\text { consults caregivers } \\
\text { by phone }\end{array}$ & Yes \\
\hline $\mathbf{E}$ & $\begin{array}{l}\text { Checked in } \\
\text { the birth } \\
\text { centre, } \\
\text { possible to be } \\
\text { send back } \\
\text { home }\end{array}$ & $\begin{array}{l}\text { Yes } \\
\text { Hospital } \\
\text { support } \\
\text { available }\end{array}$ & $\begin{array}{l}\text { No transport } \\
\text { needed, } \\
\text { caregivers } \\
\text { change room }\end{array}$ & $\begin{array}{l}\text { Digitally transferred, } \\
\text { community midwife } \\
\text { has face-to-face } \\
\text { contact with } \\
\text { caregivers }\end{array}$ & Yes \\
\hline $\mathbf{F}$ & $\begin{array}{l}\text { Checked } \\
\text { during home- } \\
\text { visit }\end{array}$ & \begin{tabular}{|l} 
No \\
Hospital \\
support \\
available \\
\end{tabular} & $\begin{array}{l}\text { No transport } \\
\text { needed, } \\
\text { caregivers } \\
\text { change room }\end{array}$ & $\begin{array}{l}\text { Medical history on } \\
\text { paper, community } \\
\text { midwife has face-to- } \\
\text { face contact with } \\
\text { caregivers }\end{array}$ & Yes \\
\hline $\mathbf{G}$ & $\begin{array}{l}\text { Checked } \\
\text { during home- } \\
\text { visit }\end{array}$ & $\begin{array}{l}\text { No } \\
\text { Hospital } \\
\text { support } \\
\text { available }\end{array}$ & $\begin{array}{l}\text { No transport } \\
\text { needed, } \\
\text { caregivers } \\
\text { change room }\end{array}$ & $\begin{array}{l}\text { Medical history on } \\
\text { paper, community } \\
\text { midwife has face-to- } \\
\text { face contact with } \\
\text { caregivers }\end{array}$ & $\begin{array}{l}\text { No and no } \\
\text { maternity care } \\
\text { assistance at night } \\
\text { at home }\end{array}$ \\
\hline
\end{tabular}


Hitzert, M., Boesveld, I.C., Hermus, M.A.A., Graaf, J.P. de, Wiegers, T.A., Steegers, E.A.P., Akkermans, H.A. Quality improvement opportunities for handover practices in birth centres: a case study from a process perspective. Journal of Evaluation in Clinical Practice: 2018, 24(3), 590-597

Table 3. Results of the 7 birth centres on quality obstacles from a process perspective

\begin{tabular}{|l|l|l|l|l|l|l|l||}
\hline $\begin{array}{c}\text { Birth } \\
\text { centre }\end{array}$ & $\begin{array}{c}\text { Caregiver } \\
\text { presence } \\
\text { on arrival }\end{array}$ & $\begin{array}{c}\text { Contact } \\
\text { during } \\
\text { handover }\end{array}$ & $\begin{array}{c}\text { Use of } \\
\text { electronic } \\
\text { health } \\
\text { records }\end{array}$ & $\begin{array}{c}\text { Caregivers } \\
\text { knowledge } \\
\text { on } \\
\text { procedures }\end{array}$ & $\begin{array}{c}\text { Familiarity } \\
\text { with team } \\
\text { members }\end{array}$ & $\begin{array}{l}\text { Continuity } \\
\text { of familiar } \\
\text { caregiver }\end{array}$ & $\begin{array}{l}\text { Continuity } \\
\text { of care for } \\
\text { client }\end{array}$ \\
\hline \hline $\mathrm{A}$ & Not present & Not direct & Multiple & Adequate & Yes & No & Yes \\
\hline \hline $\mathrm{B}$ & Not present & Direct & Multiple & Adequate & No & Yes & No \\
\hline $\mathrm{C}$ & Not present & Direct & Multiple & Inadequate & No & Yes & No \\
\hline $\mathrm{D}$ & Present & Direct & Multiple & Adequate & Yes & Yes & Yes \\
\hline \hline E & Present & Direct & Single & Adequate & No & Yes & Yes \\
\hline F & Not present & Direct & Multiple & Inadequate & No & No & Yes \\
\hline \hline$G$ & Not present & Direct & Multiple & Adequate & No & No & No \\
\hline \hline
\end{tabular}

